\title{
Regional Development Planning According to Economic and Natural Resources
}

\author{
Amany Ragheb, Rasha.A. EL-Ashmawy
}

\begin{abstract}
The sustainable urban development has emerged to achieve a better life and prosperity for the individual in modern society and in various areas of life. The aim of this study represents new planning vision for the western region of Delta to distribute it in new settlements out of Delta. It is a broad vision of balanced development goals, along western region of Delta, directing its physical expansion towards new potential growth centers (Poles). We applied the theory of the strategy of growth poles for economic and social growth potentials are selected to intensify the elements of development, activating the optimal use of its human and natural resources by working to convert some of its cities into a group of growth poles and mitigation centers. The output result of SWOT analysis leads to three main major growth poles, five sub growth poles and many linked growth poles specialized developmental functions that become competitive attractions for the existing urban areas according to human distribution, efficient use of economic resources, natural resources, and industrial technology. This leading activities and adequate infrastructure to not to waste development resources and investments available on large areas in the region.
\end{abstract}

Keywords: Sustainable urban development; Regional planning; National Strategic; quality of life; Growth poles; Alexandria region.

\section{INTRODUCTION}

$\mathrm{T}$ he concept of sustainable urban development aims at beginning a large-scale political, economic, and cultural project pleasantly linking environmental requirements with those of economic development from a longstanding viewpoint [1]. The interests of future generations are therefore explicitly set next to those of current generations, and the processes of economic optimization are constrained by the respect of the limited reproduction capability of the biosphere [2].

The sustainable urban development plan in its scientific and practical sense is the main path leading to progress to achieve a better life and prosperity for the individual in modern society and in various areas of life which is an imperative need for the developing countries to coordinate efforts and energies and invest them perfectly [3]. This is the outcome of sectorial plans and the coordination between their priorities for the purpose of reaching a national development plan [4]. Facing the topic of sustainable development from the point of view of cities looks gradually more critical.,

Manuscript received on March 27, 2021.

Revised Manuscript received on April 02, 2021.

Manuscript published on April 30, 2021.

* Correspondence Author

Amany Ragheb*, Associate Professor, Delta University for Science and Technology, Egypt.

Rasha.A. EL-Ashmawy, Assistant Professor, Delta University for Science \& Technology, Egypt.

(C) The Authors. Published by Blue Eyes Intelligence Engineering and Sciences Publication (BEIESP). This is an open access article under the CC BY-NC-ND license (http://creativecommons.org/licenses/by-nc-nd/4.0/) the city cannot be separated in its constituents from the society [5]. In addition, many of the problems that the city suffers are the result of factors or problems outside the city itself, as the solutions to these problems are not only limited to methods inside the city, but also outside it [6].

The evaluation cities along this region are agents of social, cultural, economic, industry, technological and political changes and advancement" there are many challenges and opportunities of urbanization, such economic development and employment opportunities, developments of new markets, gains of higher productivity, natural resources, benefitting from proximity and low transport costs, cities as centers offering different services, education and health care, innovation, culture, and creativity, as well as local-global linkages [7].

Among the new development areas are the outskirts (the borders) of the Egyptian country which is characterized by the limited population level. Since these areas are of special importance for national security and the strategic dimension, the necessity of the reconstruction of these areas is illustrated by the establishment of various development projects.

Within the framework of the country's approach aimed at leaving the Delta and the Green Valley to the Egyptian geographical space and increasing the populated area and considering the successive regional and international changes and their impact on Egypt and in light of the growth factors from natural material and human resources and sites [8]. it is easy observe the spread of natural resources over the entire territory of the Egyptian country, especially Development areas on the outskirts of the Egyptian country (South Sinai North Sinai - New Valley - Red Sea - Matrouh) Governorate, which are areas far from the populated area where encouraging the urban movement needs more important motivations depending on the type of population that can be moved to these areas according to their economic and social characteristics so that they can be motivated to migrate to these areas and become competitive attractions for the existing urban areas.

The study focuses on Alexandria region as it includes one of the border governorates (Matrouh Governorate) and it aims to bring out a comprehensive development to Matrouh desert and work to make the best use of the desert back of the region and the coastal areas in an effective contribution to decrease the population intensity in the overcrowded Delta regions, with the maximum benefit of the available resources in this region [9]. 


\section{Regional Development Planning According to Economic and Natural Resources}

\section{RESEARCH PROBLEM}

The research problem can be defined as follows:

Putting the western region of Alexandria Province for a period of nearly half a century under the administration of the border forces has resulted in its weak relationship with the Egyptian urban in the Valley and Delta. This leads to the overpopulation in the Valley and Delta, special Alexandria and Cairo cities that reaches to 7, 15 million, respectively, which lead to increase the pressures on natural resources and agricultural lands Fig 1 [10]. It is needed to redistribute the population according to the Egyptian geographical landscape. The presence of vast desert lands along the Egyptian country with multiple promising natural resources with various fields of human activity that have not been exploited yet. The limited population on the outskirts of the north western side of Egypt considering the strategic importance of these areas, especially for the national security. In additional, there are many development plans in the region does not depend on the distribution of the natural resources [11]. of the study area, there is no clear methodology that bears in mind the distinct resources and potentials for them to utilize these areas and benefit from them in solving problems that deter development. Although there are many development plans in the region, there is no clear methodology that bears in mind the distinct resources and potentials for them to utilize these areas and benefit from them in solving problems that deter development.
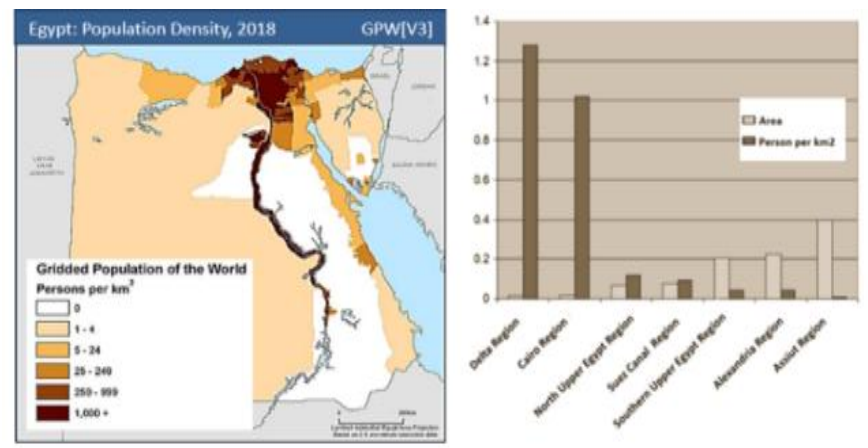

Fig.1. Population Density.

\section{RESEARCH METHODOLOGY}

To reach review of the previously defined goals, the research goes through the following stages: Reviewing the concepts of development and regional planning, clarifying the role of both regions and cities in the development process, studying the types of regional development strategies and how to achieve them. In this study we are using the quadrant analysis program (SWOT) for the collected data which published reports by Urban Communities Authority, 2018, that shows the containment of a set of opportunities and the various potentials that must be optimally exploited to ensure the balance in the region. The output analysis is represented by using a computer program (Surfer 16) to carry out the regional analysis of the existing urban centers and study their economic factors, their potentials [12]., and the proposed projects for their development to reach development pillars with specialized functions. Setting a balanced regional and natural development vision for Alexandria Province that clarifies future urban development centers in one framework that leads to a balanced urban expansion for the region, taking into account all the region's potentials and the real needs of these residents according to their economic and social characteristics [13]., to form a clear analysis methodology that can be followed in the development of the region and similar regions and set some recommendations that may contribute to the development of the region [14].

\section{DEVELOPMENT AND REGIONAL PLANNING}

There is a strong and imperative relationship between development and planning, as it is the relationship between the goal and the way to achieve it [15].Regional development is "those deliberate changes that occur in a region's condition with the aim of improving the living conditions of its residents, reducing human spatial disparities between its various parts, by optimizing the use of its resources, and improving the efficiency of its human capabilities in all its details [16].Most of the development studies conducted by the World Bank, United Nations organizations and other development research centers in the world always discuss the issue of development within the framework of three main aspects. [17]. These aspects i.e., the human, place, and administration, are the basic foundations for achieving development anywhere, anytime and under any conditions [18]. It is not enough for the society to adopt policies aimed at economic development if it does not have the administrative capacity and efficiency that transforms these policies from mere words into an implementation plan that conveys them into a tangible reality [19]. For the development goals to be achieved, economic policies must be aligned with ongoing programs to develop the administrative process, update work methods, and review advanced mechanisms of administrative work along with the structures of its organizations, and the relationship of these organizations to each other [15].The presence of three approaches through which planning regions are defined (relying on the traditional national administrative network as planning spatial frameworks, defining planning regions in case administrative regions do not fit the regional development goals [15], establishing completely new administrative units known as economic regions) "Fig 2 ". Cities play an important role in the two processes: regional growth and regional development because the existence of these cities is a prerequisite - if not the only condition - for the transition of society from the stage of a single economy to the stage of a diversified economy as its functions multiply [20].Besides, these cities are also the main force behind the regional transformation as major sites for the vital inputs needed for production and development, their presence in these locations and their functions to serve regional areas make them able to spread development to the smaller cities and to the urban center, especially in the developing world [21].

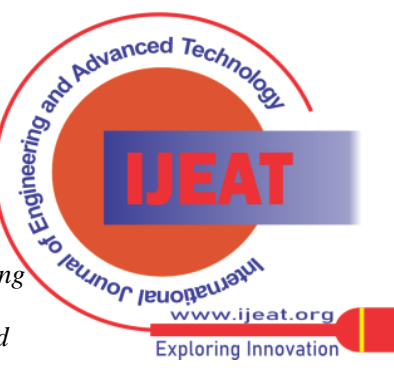




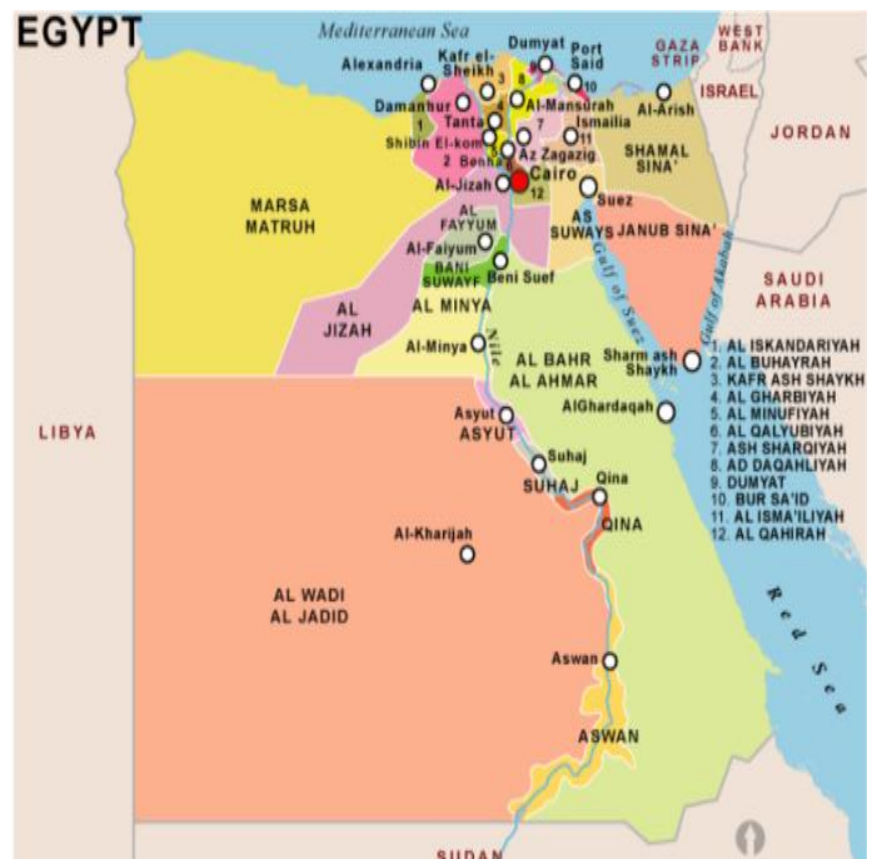

Fig. 2. Population Map of Egypt's governorates. (http://english.ahram.org.eg/Media/News/2012/10/21/2012-6348641725 24451773-445.jpg)

\section{A. Development strategies.}

The developing countries that take planning to achieve development suffer from the phenomenon of unbalanced growth between the different regions (Regional Unbalanced Growth) due to the absence of a clear strategy for regional development. Generally, strategies are concerned about the way to achieve a set of goals and objectives through specific paths that work to determine the amount and type of resources that must be allocated to achieve these goals and objectives [15].Regional planning is the regional distribution of the elements of the national plan according to the problems, needs and constituents of the country's various regions. Various regional development strategies are used to correct growth imbalances - regional disparities, with the multiple objectives that national planning seeks to achieve, namely (spread strategy - concentration strategy - growth poles strategy) [22].

\section{B. Growth Poles Strategy.}

Growth center strategies have been practiced for long periods by the governments of the least developed countries. In addition, the growth center's policies have become compatible with the growing importance of national development plans in an increasing number of countries [23]. There is a significant note that even countries that have been short of capital, workforce, and organizational resources, separately or collectively, have followed regional or local planning that includes one or more growth poles or centers, which are countries that differ widely in their area, population, level of income per capita, degree of urbanization, industrialization, and political composition [24]. In accordance with the strategy of growth poles, a limited number of regions that have economic and social growth potentials are selected to intensify the elements of development, so that these areas turn into growth poles in relation to the surrounding areas, which develop themselves first, and then spread development through these areas through the available Leading Activities. This strategy requires political and administrative decentralization, and adequate infrastructure [25]. The establishment of new cities comes as a solution to reduce the population pressure on the existing cities, redraw the demographic and urban map, and invest the available resources in deserts and coasts, with the aim of increasing national income, providing job opportunities, establishing industries in specific areas to benefit from the economic output at the planning regional level and preparing the proper conditions to attract capital in the new regions and cities [24]. The concept of growth poles is one of the most important theoretical frameworks that attempted to explain the variation in regional development, which holds that growth does not occur in all regions at the same time, but appears in the form of points or poles of growth and with a different intensity in some nodal places that are formed in economic or geographic spaces Fig 3, which are often large urban settlements that operate as centers of growth because they differ in their functional specialties on the one hand, and on the other hand in their local potentials, which makes them points of attraction for the types of innovation [26].

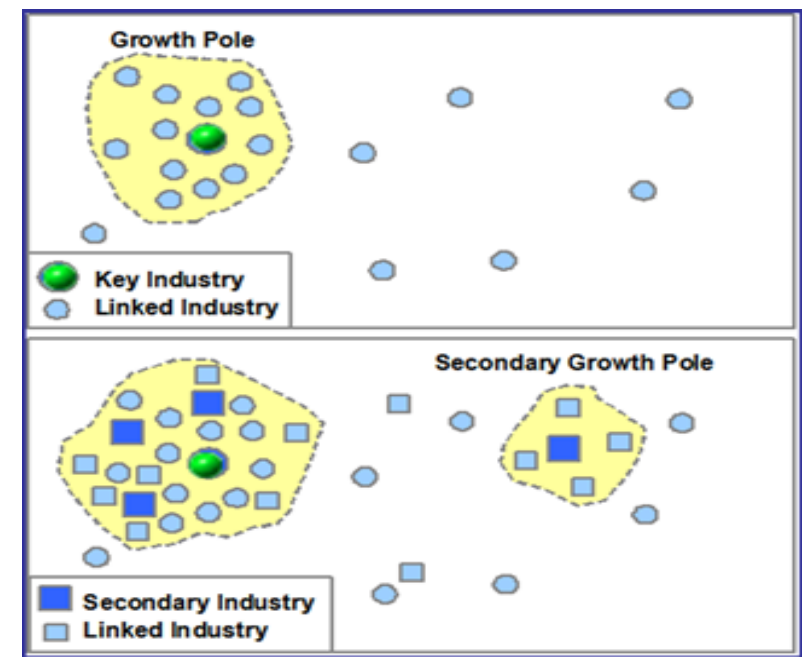

Fig. 3. Shows how the main and the secondary growth poles lead growth direction of cities [23].

The basic principles of the Peruvian concept of the growth pole can be summarized in the following stages [27].

The occurrence of growth in an economic space represented in a field of forces that leads to interactions between economic partnerships Table 1.

- Growth is focused on large economic institutions with the ability to absorb and generate innovations, and these institutions are growth poles.

- The dominance of the growth poles on the economic space and their impact on other economic institutions by spreading innovations through different channels.

The growth pole theory consists of three basic principles or concepts:

- The concept of leading industry and stimulating economic entities.

- The concept of polarization results and pooling savings (accumulation of economies).

- The concept of the outcomes of the effects spread.

Sciences Publication 


\section{Regional Development Planning According to Economic and Natural Resources}

Table- I: Friedmann's Four Stages Spatial Development Model.

$$
\odot-\odot-\odot \odot-\odot
$$

Stage 1: Local centers are relatively independent and there is no typical structure hierarchy.

Each city is in the center of a small regional county.

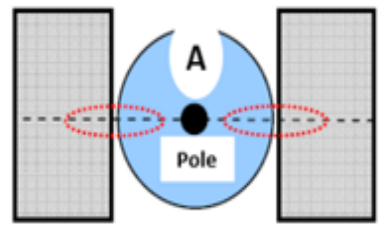

Stage 2: Single national nucleus A

A typical initial period of industrialization that shows expulsive margins, labor moves, and the core migrates. The national economy turns into a single metropolitan region.

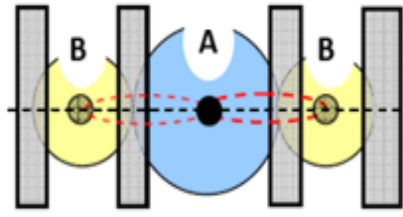

Stage 3: A single national nucleus A

Strong sub-nuclei in the periphery, B. During the stage of economic maturity, secondary nuclei are formed. In this way, the margins at the national level are reduced to smaller margins within the metropolitan area.

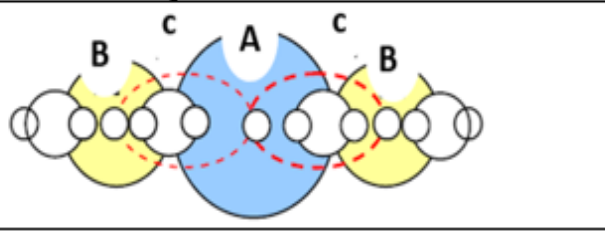

Stage 4: Independent functional system from cities.

An institutional complexity marked by national integration, Maximum energy for growth

The concept of "growth pole" in the form of growth center strategies for regional planning has become one of the preliminary steps taken by governments to strengthen the influence of public policy to reshape spatial organizations. The attractiveness of the growth pole theory as a planning political tool is linked to several reasons:

- Its good suitability for enhancing growth and achieving development.

- Few costs of focusing investments on limited growth points, from the point of view of public spending.

- The spread effects resulting from the growth point help in solving some problems of the surrounding lagging regions (periphery area) at this point [28].

- The importance of the growth axis approach is linked to the fact that it provides a means for integrated analysis and regional growth, which provides us with an alternative to the linear model of transport programming. This analysis has a great advantage, given its consideration of the regional urban transport network architecture [29].

The considered localization of the elements of development or growth in a selected point of a specific space is the solution adopted by the regional analysis to establish and promote regional development, reduce spatial disparities in the pillars of this development and its potentials [30], and confront its constraints, whether within the region or between the various regions.

Regional analysis represents a completely successful attempt to synthesize the spatial and economic. in one research perspective, and to understand the processes that constitute the basis of its work and its effectiveness, which are spatial construction and the nature of development [30].

After reviewing the theoretical foundations and applied experiences of the phenomenon of growth centers, which were applied in some developing countries in the previous part, Egypt can solve its urgent population problem of redistributing its population as well as activating the optimal use of its human and natural resources by working to convert some of its cities into a group of growth poles and mitigation centers. This will be presented in the next part.

\section{CASE STUDY}

Alexandria region is located at the western region of the north of the republic Fig 4, It represents a coastal strip with a length of $560 \mathrm{~km}$ and extends south to Assiut (Central Upper Egypt) and east to the borders of Cairo and Delta regions and west to the Egyptian-Libyan border and $400 \mathrm{~km}$ deep towards the south of the Mediterranean coast [31].The region is considered the western overland entrance to Egypt from Morocco through Al Salloum port and the main northern sea entrance from the Mediterranean countries and Europe through the port of Alexandria.

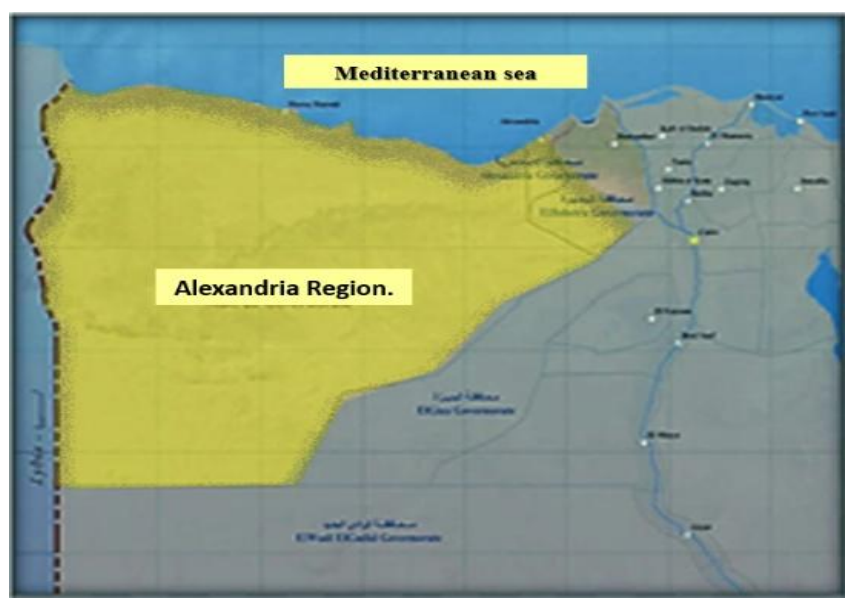

Fig. 4. Alexandria Region.

The researcher sees through the study that Matrouh governorate as a border governorate which requires development as a priority due to its large area and small population. In addition, it contains many opportunities and potential's that must be exploited optimally in a way that ensures the achievement of balance in the region. The following is a quadrant analysis (SWOT) Table 2 that shows the Matrouh governorate containment of a set of opportunities and the various potentials that must be optimally exploited to ensure the balance in the region.

Published By:

Blue Eyes Intelligence Engineering \& Sciences Publication

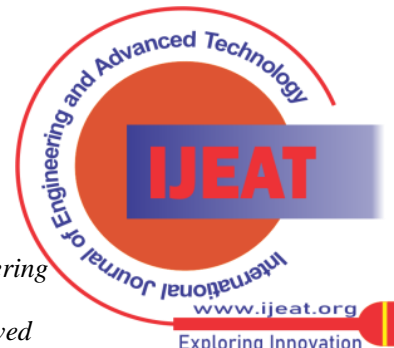
Exploring Innovation 
The main urban centers are linked to the coastline, and the internal urban centers rarely exceed $50 \mathrm{~km}$ to the south of the coastline in addition to the spacing of urban centers and their small size which indicates that the urban developed areas are noticeably small.

The presence of urban centers along the coastline and the direct backline is linked to either the sea or the reasons for cultivation of an adequate amount of rain and the rich soil, especially the cultivation of some tree crops [32].Matrouh Governorate is characterized by a low population density, as the total density does not exceed 1.12 people / $\mathrm{km} 2$ and reaches about 58.4 people / $\mathrm{km} 2$ when considering the populated area of the governorate only, which amounts to $4000 \mathrm{~km} 2$, with a relative increase in the centers of Hammam, Matrouh and Siwa. The urban gatherings in the study area were established on economic, military or tourist basis.The population of the coast varies according to the way of life and is divided into the eastern region, the central region, the western region, and the desert back. Agriculture is the main activity for the residents of Matrouh Governorate, and the service activity occupies the second position with a wide difference from and the main activity. It is noticeable that the percentage of workers in the trade, restaurants and hotels increases due to the displacement of many individuals, especially from Alexandria Governorate to the north coast.From (SWOT) analysis can selects several Growth Poles to work as pillars of integrated economic activity groups in a way that achieves work and preserves the available development resources and investments established on broad areas in the region with the optimal utilization of the available infrastructure and human resources along with the efficient use of economic resources.

\section{A. Growth Poles for economic activity groups.}

Urban communities in its broad concept include all elements of human uses that are integrated in the formation of the residential and living environment of the human being and constitute a socio-economic interaction for the members of society. Urban communities inside Matrouh Governorate are divided into eight centers, Fig 5 (Matrouh, Al-Hamam, Al Salloum, Al-Dabaa, Sidi Barani, Siwa, Al-Alamein, and Al-Nujila) and eight cities (a city in each center), where the Bedouins represent $90 \%$ of the population.In terms of activating the utilization of the resources and potentials of the study area, the research studies urban gatherings in the study area as well as the characteristics of the workforce in it. In addition, the research studies analysing the potentials and resources of the main development in the region as well as the potentials of economic projects to direct development toward the growth poles [33], by doing a regional analysis of the existing urban centres based on these potentials.

This is done for the purpose of reaching centers with specialized developmental functions that become competitive attractions for the existing urban areas, through the availability of leading activities and adequate infrastructure to not to waste development resources and investments available on large areas in the region with the optimal use of the infrastructure and human resources available and developing them along with the efficient use of economic resources.

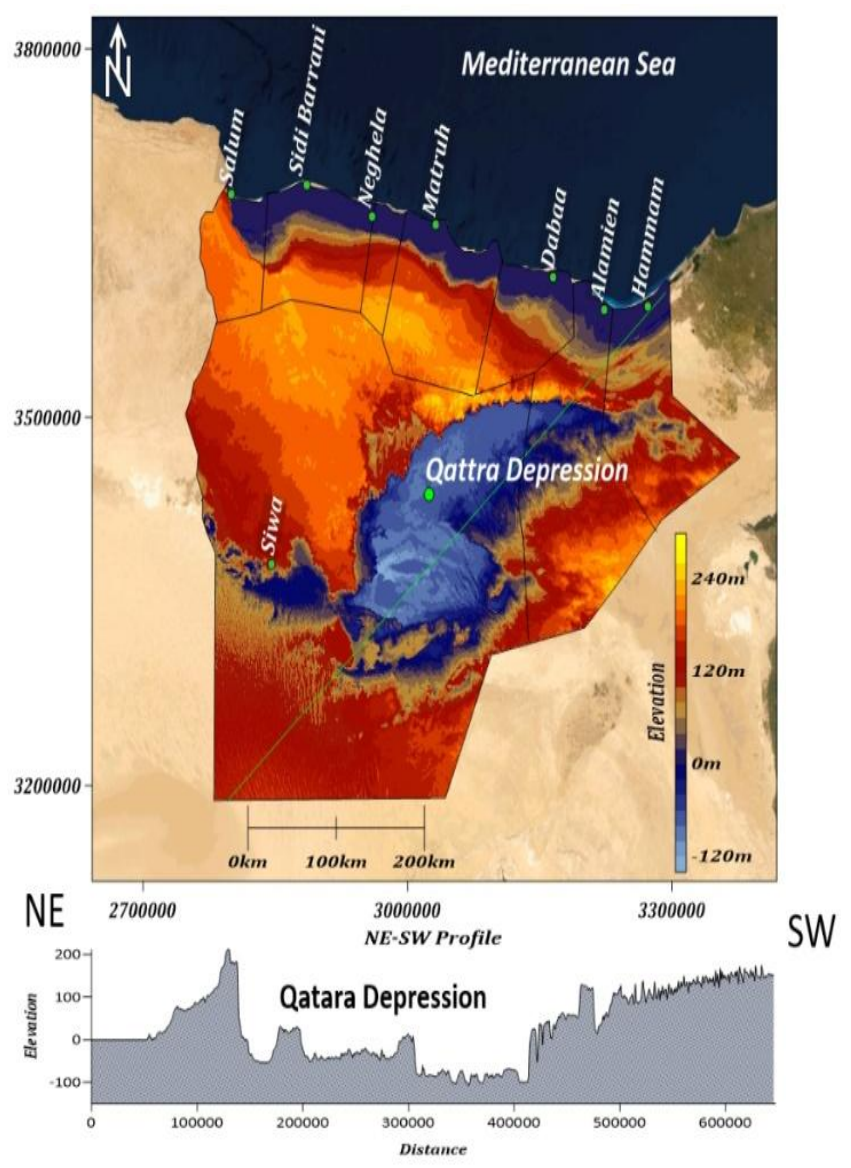

Fig. 5. shows the urban centers in Matrouh Governorate (Researchers).

The researcher uses a computer program (Surfer) to carry out the regional analysis of the existing urban centers and study their economic factors, their potentials, and the proposed projects for their development to reach development pillars with specialized functions.

\section{B. Regional analytical field research study.}

Carrying out a regional analysis of the existing urban centers based on the availability of the elements of development (Fig $6,7,8,9,10)$, to direct development toward the growth poles. The analysis depends on the development potentials and the availability of resources as follows: (human resources, urbanization and population, characteristics of the workforce, infrastructure, water resources, land resources, raw materials, projects), and that to Maximizing the benefit of the potential of each of the governorate centers. Identifying the cities that are pillars of the integrated economic activity groups Fig11, and which have the potential for economic and social growth to intensify the elements of development, so that these areas can turn into growth poles in relation to the surrounding areas. Thus, they develop themselves first and then spread development through these areas "Development diffusion" [34].The activity distribution based on the centres clarifies the importance of the Al Alamein centre in the extractive and tourism industries and the importance of Matrouh, $\mathrm{Al}$ Hammam and Al Dabaa in all other activities. The development of the economic structure reflects the high relative importance of tourism and commercial activities,

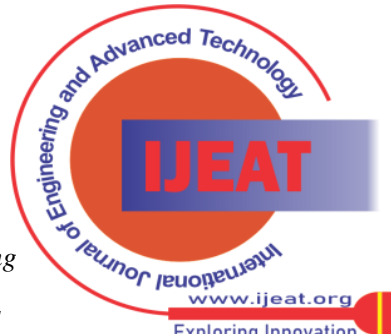




\section{Regional Development Planning According to Economic and Natural Resources}

as well as the growth of the services sector at the expense of agricultural, industrial, and mining activities whose relative importance has declined, which reflects the shift in the economic strength of the province in favor of service activities and at the expense of commodity production activities. There are many mineral and petroleum resources in the study area upon which industrial societies can be built. The results show that the city of Marsa Matrouh occupies the first place in the potentials of agricultural development, Siwa in the second place, $\mathrm{Al} \mathrm{Hamam}$ and $\mathrm{Al}$ Alamein in the third and fourth places, followed by Al Dabaa, the Najila, Sidi Barani and Al Salloum. The city of El Alamein is ranked first in the potentials of industrial development, Marsa Matrouh is second, Al Hamam and Siwa are third, Al Dabaa is fourth followed by Sidi Barani, Al Salloum, and El-Nagla.The city of Marsa Matrouh is ranked first in the potentials of environmental development and the Al Hamam is second, followed by Al Alamein, Al Dabaa, Al Salloum, Siwa, Sidi Barani and Al Nagila.The city of Marsa Matrouh is the first major development center for projects in the governorate, followed by El Alamein and Siwa in the second place.

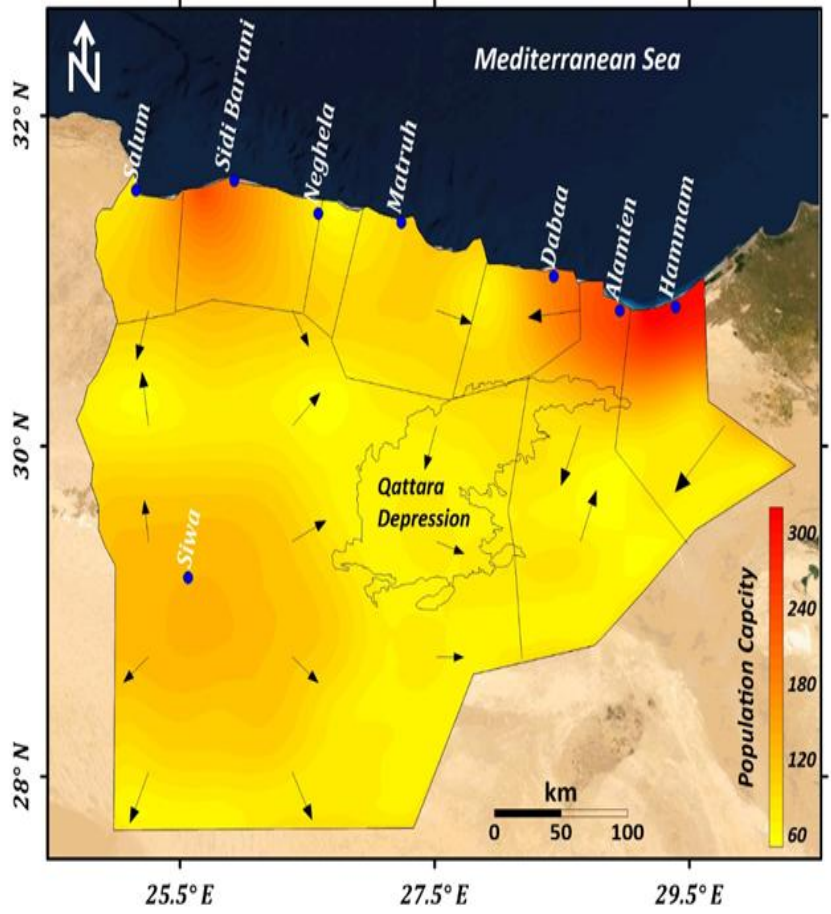

Fig. 6. shows the population Capcity in the governorate centers (source: the researcher).

Table-II: Explains the SWOT analysis of Alexandria region.

S1. Matrouh governorate enjoys a picturesque nature, with many natural resources that pave the way for a development boom.

S2. The distinguished location in the far northwest of Egvpt, which represents the western gate of Egypt and an important strategic axis for development, linking Egypt with Morocco and the countries of the northern Mediterranean.

S3. The region is characterized by renewable natural resources that can be reconsidered and transformed into production resources and a population attraction that reduces pressure on agricultural lands in the Nile Valley, and encourages the stability of dry farming communities S4. The presence of fish wealth of the finest species at a depth of $60 \mathrm{~km}$ which has not been best utilized until now.

S5. The availability of pastures on which three-quarters of the pastoral wealth of that region depend and its role as an economic attraction for the population. The actual number of grazing animals can be increased if the nomads and herders can extend their pastoral activity in the internal plateau environment.

S6. The presence of a wealth of natural plants and herbs can cause a boom in the future of the region if those herbs are employed correctly in a laboratory to serve in the aromatic and medicinal fields in addition to protecting them and working to multiply them.

S7. Mineral wealth represented by multiple types of minerals such as manganese, iron, and natural gas

S8. Drainage ponds are very large with suitable soil for cultivation.

S9. Wind speed is of great and increasing importance because it is used as a source of energy in addition to solar energy.

S10. Barley, which is multi-purpose, is considered the appropriate crop for the region due to its drought tolerance and its short growth period

S11. The study area is considered one of the most important olive production areas in Egypt S12. It is a good potential for medical and adventure tourism

\section{SWOT Analysis}

Helpful

Harmful

01. The country focuses its efforts on reformulating the Egyptian economy system in order to allow multiple economic activities that promote growth through the tendency to settle various projects in new areas with promising development potentials.

02. In light of the tendency towards the reconstruction of the desert areas and the optimization of the various resources, especially in the tourism, industrial and agricultural fields, Matrouh Governorate is cooperating with the ministries and relevant authorities to provide the appropriate infrastructure such as various forms of transportation, supplies of drinking water, sanitation lines, electricity and communication networks in addition to the others services that would qualify the governorate to be a leader in attracting future investments and

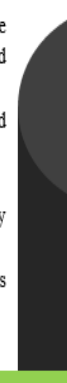

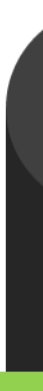
Strengths INTERNAL
W1. Not to take advantage of flood water, most of which is lost in the sea.

W2. The problem of seawater interference as a result of increasing pumping or deepening the existing wells W3. Imbalance between population and these resources (one or more individuals per square kilometer). W4. The presence of wide marshes as a result of the accumulation of flood water while not utilizing it. W5. Social transitions from nomadism and herding to urbanization and animal husbandry in closed locations. W6. Putting hands on large areas of land along with the increase in building land prices.

W7. Removing some natural plants to grow some crops, especially after the connection with Al- Hamam Lake.

W8. Limited government services in the health care and education sectors. achieving the development boom that is commensurate with its potentials.

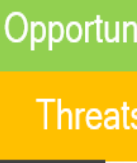

\section{EXTERNAL}

Published By:

Blue Eyes Intelligence Engineering

\& Sciences Publication

(C) Copyright: All Rights Reserved
T1. The extension of mine areas to a distance of approximately 450 kilometers, which is called "Devil's Gardens", where it prevents the residents of the region and the Egyptians in general from approaching them or benefiting from more than a million acres of the best agricultural lands surrounded by booby traps.

T2. Residents of the land are fallowing a few areas of agricultural lands and converting them into building lands.

T3. Overgrazing in many areas and its direct impact on the region's biological diversity.

T4. Increasing urban expansion and growth of the tourism sector without planning including building hotels and resorts on archaeological areas and not taking into account the preservation of the biosphere and its environmental characteristics. T5. The randomness and confusion in establishing tourist resorts is the biggest evidence of the dangers of random activities on the environment, as the calls to establish tourist villages without leaving empty spaces between them removed large areas of sand dunes, and the yard of plants, animals and other creatures in the region. T6. Increase in the catch of birds, mammals and reptiles for trafficking, which has affected endangered species.

T7. Increased collection of wood and medicinal plants for trafficking. 


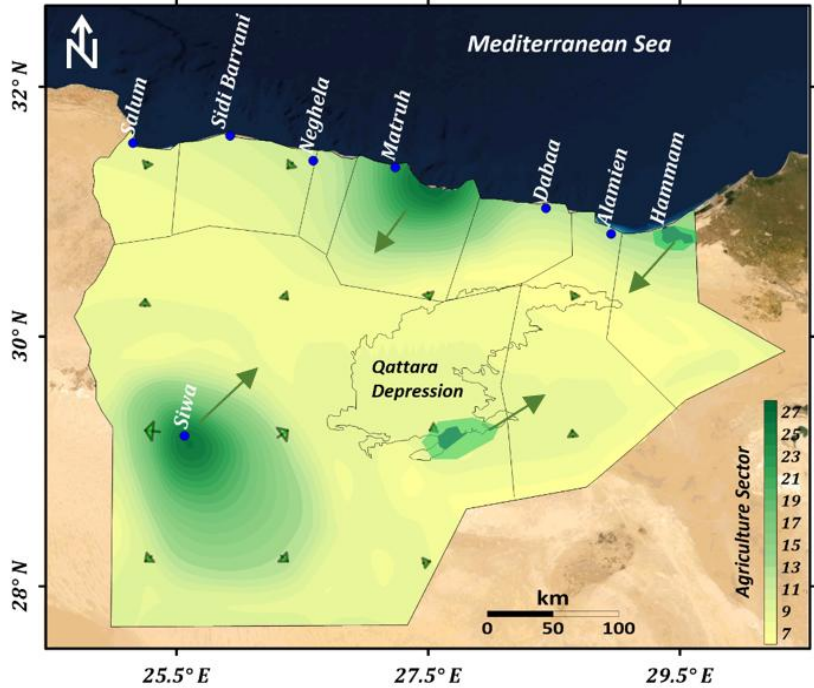

Fig. 7. shows the concentration of Agriculture sector projects in the governorate centers (source: the researcher).

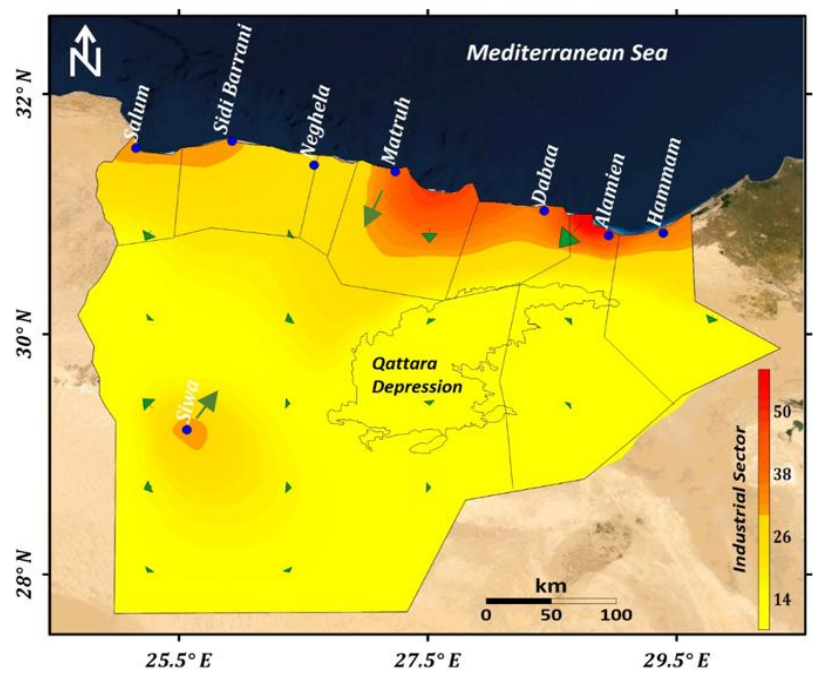

Fig. 8. shows the concentration of industrial sector projects in the governorate centers (source: the researcher).

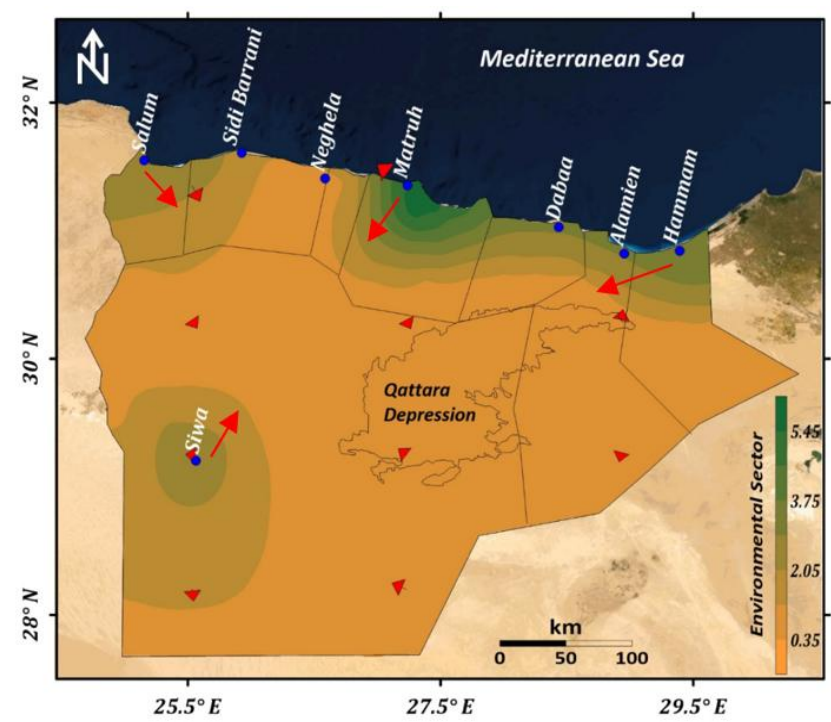

Fig. 9. shows the concentration of Environmental sector projects in the governorate centers (source: the researcher).

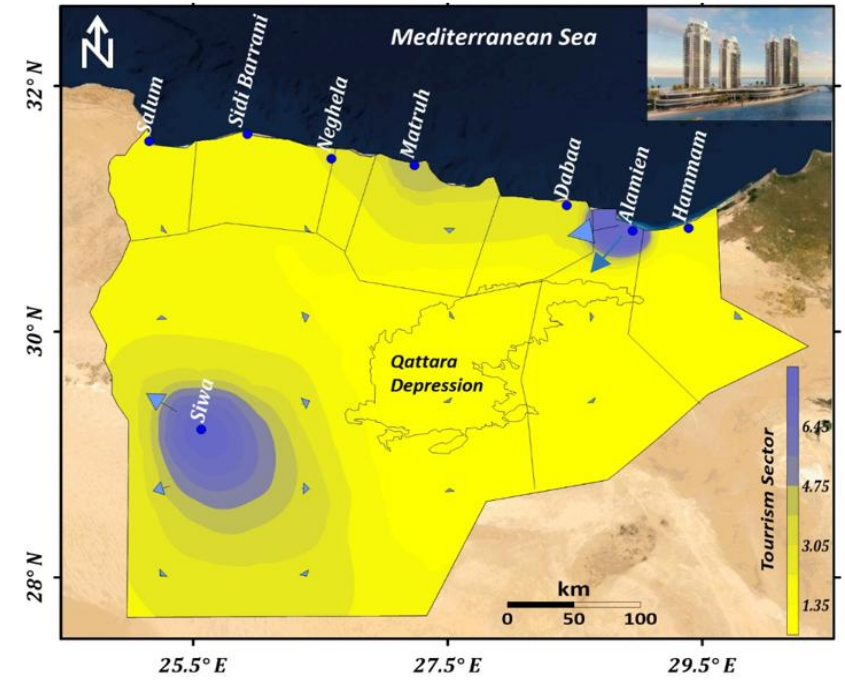

Fig. 10.shows the concentration of Tourism sector projects in the governorate centers (source: the researcher).

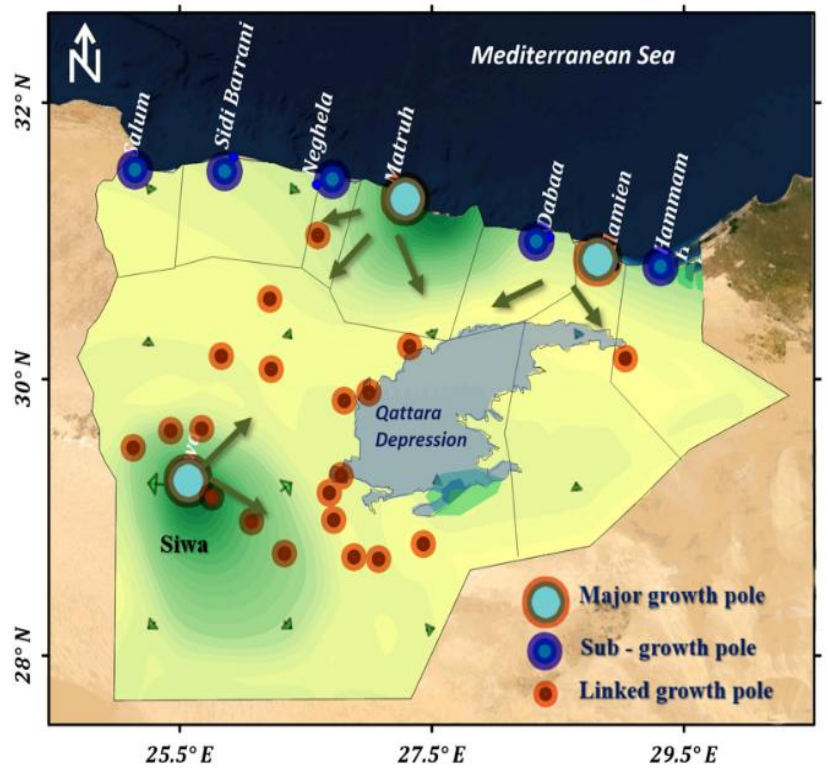

Fig. 11. shows the cities that are pillars of the integrated economic activity groups, (source: the researcher).

The research presents a proposal for developing roads between the main development pillars of the governorate and linking them by crossroads to the Nile River Valley. The proposed roads for development: (Siwa Road / Marsa Matrouh - Bawiti Road / Siwa - Alamein Link / Bahariya Oasis Road - Siwa Road / Al Salloum) Fig 12.

These roads act like new construction hubs prepared as attractions to accommodate new development projects, supplied with infrastructure facilities of electricity and water, and linked with two new cross roads from Bahariya oases once to Fayoum, then Maghaghah and the other to $\mathrm{Al}$ Coraymat, so as to move from the current narrow residential space to spread and transfer facilities and residents from the narrow valley to the new development areas, as the movement outside the valley space has become a basic requirement upon which the future of development in Egypt depends by maximizing our ability to benefit the most of the vast desert.

Published By:

Blue Eyes Intelligence Engineering DOI:10.35940/ijeat.D2368.0410421

Journal Website: www.ijeat.org

\& Sciences Publication

C) Copyright: All Rights Reserved

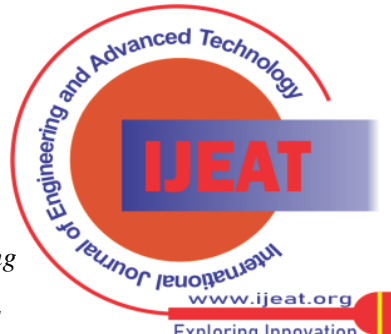




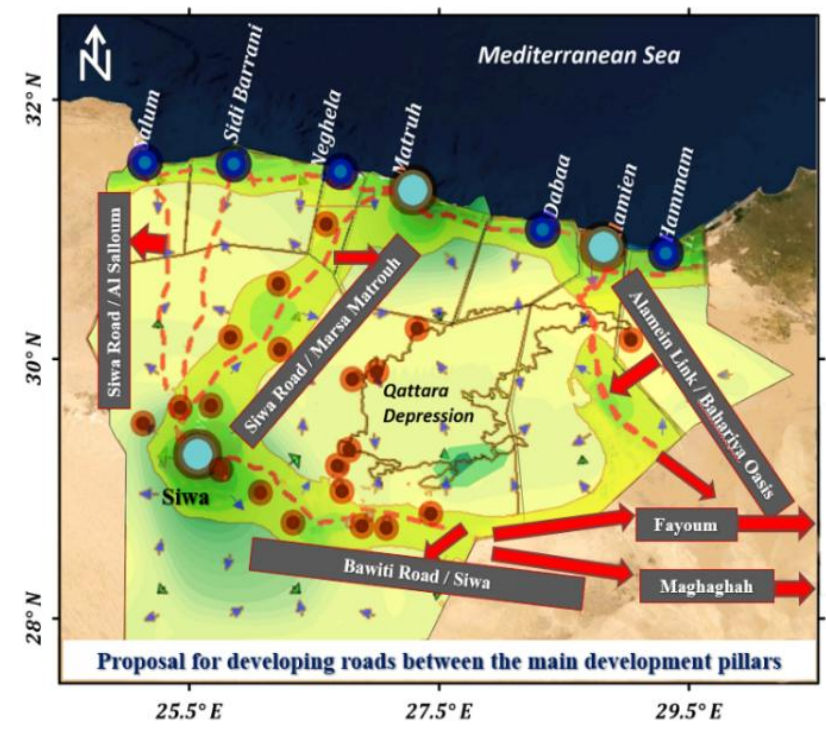

Fig. 12. Suggested roads to be developed within the governorate and itsimpact on the existing urban centers (Researchers).

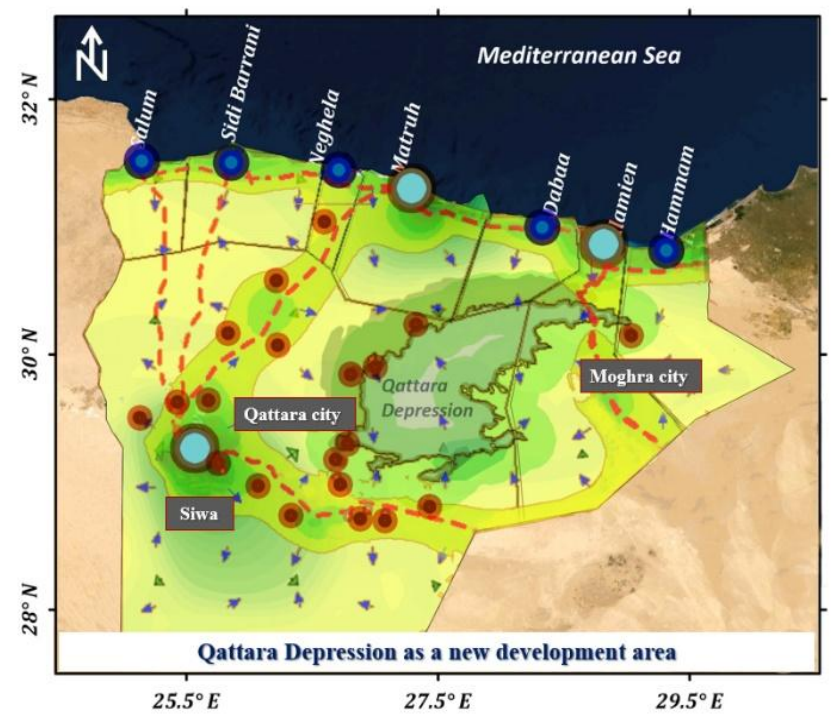

Fig. 13. Shows the impact of the dropper low project in the development of existing urban centers and Creating new development centers (Researchers).

Take advantage of the presence of Qattara Depression as a new development area, the implementation of Qattara Depression Project will create a nucleus of urbanization in the depth of the desert and on its borders along with the establishment of a group of new urban gatherings in Qattara Depression Fig13. Thus, Qattara Depression will shift from a dead dry depression to something closer to the nearby Dead Sea, but alive with energy, industry, and urbanism [35].

\section{RESULTS AND CONCLUSION}

The output result of SWOT analysis leads to three main major growth poles, five sub growth poles and many linked growth poles specialized developmental functions that become competitive attractions for the existing urban areas according to human distribution, economic situation, natural resources, and industrial technology. This leading activities and adequate infrastructure to not to waste development resources and investments available on large areas in the region with the optimal use of the infrastructure and human resources available and developing them along with the efficient use of economic resources. The researcher's developmental vision in this study is based on a set of main pillars such as development of road network, taking advantage of the presence of Al Qattara depression as a new development area for agriculture development which depend on ground water, establishing basic and medium development centres for the development of the region. development of roads between the main development pillars of the governorate and linking them to the Nile River Valley as well as with two new crossroads from Baharrya Oases to $\mathrm{Al}$ Fayoum, then Maghaghah, and then $\mathrm{Al}$ Coraymat. Urbanism within Matrouh Governorate is characterized by the absence of a specific system or clear rules based on which urban gatherings prevail, where the urban structure within the governorate is controlled by natural factors, infrastructure factors, sites of potentials and economic activities (economic determinants). The implementation of Qattara Depression Project will create a nucleus of urbanization in the depths of the desert and on its borders along with the establishment of a group of new urban communities in Qattara Depression. Thus, Qattara Depression will be transformed from a dead dry depression into something closer to the nearby Dead Sea, but live with energy, industry, and urbanism. The development of Marsa Matrouh city it should appear in points or growth poles. Development of the scope of the city of Marsa Matrouh and the city of Siwa as two main growth centers due to the development and economic activities that the two cities enjoy. The location of the city of Marsa Matrouh in the center of the governorate, in addition to choosing Al Alamein and Al Salloum as second-level development centers with Matrouh and Siwa to form development pillars with specialized functions. The researcher proposes establishing a new city at the southern edge of Qattara Depression, which will be the nucleus of a large development city with a distinct development approach in the governorate. Development strategies depend on investing the potentials and benefits available in the region to ensure their continuity and success. This applied analysis research leads to provide a development vision which will have depend on economic situation and social repercussions at the local, regional, and national levels to achieve the optimum utilization of the available and potential resources alike. There are a set of issues that must be addressed to activate the development plan and achieve its goals. The overall reconstruction of this governorate is a national and urgent subject which should be a major target for those responsible for the planning aspects.

\section{REFERENCES}

1. Liu, Hongling, Guanghong Zhou, Ronald Wennersten, and Björn Frostell. "Analysis of sustainable urban development approaches in China." Habitat international 41 (2014): 24-32, https://doi.org/10.1016/j.habitatint.2013.06.005.

2. Peaucelle, Marc, Cédric Bacour, Philippe Ciais, Nicolas Vuichard, Sylvain Kuppel, Josep Peñuelas, Luca Belelli Marchesini et al "Covariations between plant functional traits emerge from constraining parameterization of a terrestrial biosphere model." Global ecology and biogeography 28, no. 9 (2019): $1351-1365$. https://doi.org/10.1111/geb.12937.

3. Surendra, K. C., Devin Takara, Andrew G. Hashimoto, and Samir Kumar Khanal. "Biogas as a sustainable energy source for developing countries: Opportunities and challenges." Renewable and Sustainable Energy Reviews 31 (2014): 846-859.

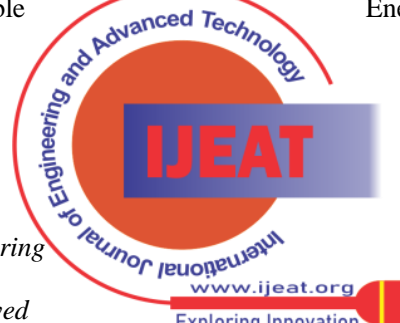
Energy 
https://doi.org/10.1016/j.rser.2013.12.015.

4. Admos O. Chimhowu, David Hulme, Lauchlan T. Munro (2019). The 'New' national development planning and global development goals: Processes and partnerships. World Development, Vol. 120, PP. 76-89. https://doi.org/10.1016/j.worlddev.2019.03.013.

5. Lehtonen, Markku. "The environmental-social interface of sustainable development: capabilities, social capital, institutions." Ecological $\begin{array}{lllll}\text { economics } & 49, \quad \text { no. } & 2 & \text { (2004): }\end{array}$ https://doi.org/10.1016/j.ecolecon.2004.03.019.

6. Hardoy, Jorge E., Diana Mitlin, and David Satterthwaite. Environmental problems in an urbanizing world: finding solutions in cities in Africa, Asia, and Latin America. Routledge, 2013.

7. Leibovitz, Joseph. "Institutional barriers to associative city-region governance: The politics of institution-building and economic governance in 'Canada's Technology Triangle'." Urban Studies 40, no. 13 (2003): 2613-2642.https://doi.org/10.1080/0042098032000146812.

8. Taher et. Al., (2019). Dramatic Loss of Agricultural Land Due to Urban Expansion Threatens Food Security in the Nile Delta, Egypt. Remote Sensing (ISSN 2072-4292), Vol (11), Issue (3) https://doi.org/10.3390/rs11030332.

9. Ragheb, A.A., EL-Ashmawy, R.A. (2020). Urban waterfront development for designing space in coastal cities. International Journal of Sustainable Development and Planning, Vol. 15, No. 3, pp. 345-352. https://doi.org/10.18280/ijsdp.150311.

10. Hanne Kirstine Adriansen (2009). Land reclamation in Egypt: A study of life in the new lands. Geoforum, Vol 40, Issue (4), PP. 664-674, https://doi.org/10.1016/j.geoforum.2009.05.006.

11. Tompkins, Emma L., and W. Neil Adger. "Does adaptive management of natural resources enhance resilience to climate change?" Ecology and society 9, no. 2 (2004)

12. La, David, Juan Esquivel-Rodríguez, Vishwesh Venkatraman, Bin Li, Lee Sael, Stephen Ueng, Steven Ahrendt, and Daisuke Kihara. "3D-SURFER: software for high-throughput protein surface comparison and analysis." Bioinformatics 25, no. 21 (2009): 2843-2844.https://doi.org/10.1093/bioinformatics/btp542.

13. Bastian, Olaf, Dagmar Haase, and Karsten Grunewald. "Ecosystem properties, potentials and services-The EPPS conceptual framework and an urban application example." Ecological indicators 21 (2012): 7-16. https://doi.org/10.1016/j.ecolind.2011.03.014.

14. Vlastimir Lekovic (2017). Key Aspects of a Balanced Regional Development of the Republic of Serbia. Economic Themes, Vol. 55, Issue (3), PP. 335-351. https://doi.org/10.1515/ethemes-2017-2019.

15. Ilcan, Suzan, and Lynne Phillips. "Develop mentalities and calculative practices: The millennium development goals." Antipode 42, no. 4 (2010): 844-874.https://doi.org/10.1111/j.1467-8330.2010.00778.

16. Baltes, Paul B. "On the incomplete architecture of human ontogeny: Selection, optimization, and compensation as foundation of developmental theory." American psychologist 52, no. 4 (1997): 366.

17. World Health Organization. Trends in maternal mortality: 1990-2015: estimates from WHO, UNICEF, UNFPA, World Bank Group and the United Nations Population Division. World Health Organization, 2015.

18. Bengtsson-Palme, Johan, Erik Kristiansson, and DG Joakim Larsson. "Environmental factors influencing the development and spread of antibiotic resistance." FEMS microbiology reviews 42, no. 1 (2018): fux053. https://doi.org/10.1093/femsre/fux053.

19. Zhang, Kun-min, and Zong-guo Wen. "Review and challenges of policies of environmental protection and sustainable development in China." Journal of environmental management 88, no. 4 (2008): 1249-1261. https://doi.org/10.1016/j.jenvman.2007.06.019.

20. Barca, Fabrizio, Philip McCann, and Andrés Rodríguez-Pose. "The case for regional development intervention: place-based versus place-neutral approaches." Journal of regional science 52, no. 1 (2012): 134-152. https://doi.org/10.1111/j.1467-9787.2011.00756.

21. Ragheb, A. A. (2018) Sustainable Urban Planning for Protecting Salt Lakes; case Study Bardawil Lake, North Sinai, Egypt.

22. Parr, John B (1999). Growth-pole Strategies in Regional Economic Planning: A Retrospective View: Part1.Origins and Advocacy. Urban Studies, Vol. 36, Issue (7), PP. 1195-1215. https://doi.org/10.1080\%2F0042098993187.

23. Odum, Eugene P. "The strategy of ecosystem development." In The ecological design and planning reader, pp. 203-216. Island Press, Washington, DC, 2014.

24. Lo, Fu-chen, and Kamal Salih, eds. Growth pole strategy and regional development policy: Asian experience and alternative approaches. Elsevier, 2013.

25. Chang, Y.Z., Zhang, Q. (2020). Industrial transfer and spatial structure optimization of Beijing, Tianjin and Hebei province. International Journal of Design \& Nature and Ecodynamics, Vol. 15, No. 4, pp. 593-602. https://doi.org/10.18280/ijdne.150418.

26. Sqour, S. M., Rjoub, A., \& Tarrad, M. (2016). Development and Trends of Urban Growth in Mafraq City, Jordan. DOI: 10.5923/j.arch.20160605.02

27. Harry W. Richardson (1981). National Urban Development Strategies in Developing Countries. Urban Studies, Vol. 18, No. (3), PP. 267-283.

28. Wijaya, A., Darma, S., Darma, D.C. (2020). Spatial interaction between regions: Study of the East Kalimantan Province, Indonesia. International Journal of Sustainable Development and Planning, Vol. 15, No. 6, pp. 937-950. https://doi.org/10.18280/ijsdp.150618.

29. Michael D. Meyer (2000). Transport Planning for Urban Areas: A Retrospective Look and Future Prospects. Journal of Advanced

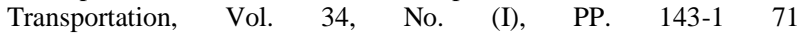
www.advanced-transport.com.

30. Mensah, Justice, and Sandra Ricart Casadevall. "Sustainable development: Meaning, history, principles, pillars, and implications for human action: Literature review." Cogent Social Sciences 5, no. 1 (2019): 1653531. https://doi.org/10.1080/23311886.2019.1653531.

31. Medany, M. A., Attaher, S. M. And Abu-Hadid (2009), Adaptation of Agriculture Sector in the Nile Delta Region to Climate Change at Farm Level, International Symposium of Impact of Climate Change and Adaptation in Agriculture, (22-23) June 2009, Vienna, Austria.

32. AbdeL-Latif, T., Ramadan, S. T., \& Galal, A. M. (2012). Egyptian coastal regions development through economic diversity for its coastal cities. HBRC Journal, 8(3), 252-262. http://dx.doi.org/10.1016/j.hbrcj.2012.10.009.

33. Effat, H. A., \& Elbeih, S. F. A. (2020), geospatial model for allocating potential urban-industrial zones in a desert: Case study Matrouh, Egypt. https://doi.org/10.1007/s40808-020-00806-w

34. John Speakman. Marjo Koivisto (2013). Growth Poles: Raising Competitiveness and Deepening Regional Integration. The Africa Competitiveness Report 2013. World Economic Forum. http://www3.weforum.org/docs/ACR/2013/ACR_Chapter2.3_2013.pdf

35. Moustafa, W.M., Hussien, R.A. and Nassar, N. (2018). Evaluation of Potential Hazards Associated with Qattara Depression as a National Hydropower Project in Egypt. Arab Journal of Nuclear Sciences and Applications, Vol 51, No (2), PP. 58 -67. Web site: ajnsa.journals.ekb.eg.

\section{AUTHORS PROFILE}

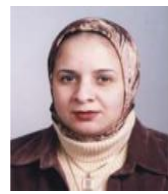

Associate Prof. Amany Ragheb, is an expert in in the field of urban planning and urban design and has taught subjects in this area for more than twelve years in reputed colleges and universities', and seven years of design experience. She has authored more than 15 research papers in reputed journals and international conferences. She is currently working as Assistant Professor at the Delta University for Science and Technology, Faculty of Engineering Department of Architecture. She obtained her M.Sc. (2005) and PhD (2009) In urban planning from Department of Architecture, Faculty of engineering, Alexandria University. Her current research interests are on sustainable urban planning, urban design and Environmental Architectural. She maintains an upward learning curve by adopting different strategies for the redevelopment of coastal areas and shorelines. Her contribution to profession includes work as a reviewer.

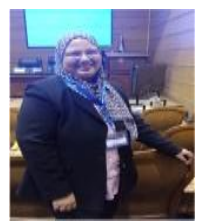

Dr. Rasha Ali El Ashmawy, spent four years as a director of the department of slums development in Daqahliya governorate, Supervised the implementation of many projects in Daqahliya province. She followed up the establishment of the Urban Observatory in Dakahlia Governorate to follow up the operational indicators of the projects of the general strategic plan of Mansoura City.Participated in the committee formed to develop a preliminary vision for planning the walkway of the people of Egypt, also Participated in reconciling the environmental conditions of the unsafe areas under the impact of industrial pollution hazards specified by the Ministry of Housing (Talkha area), She Contributed to the inventory of the inhabitants of the shelter area in Magzar in preparation for its inclusion in the replanning areas in coordination with the Fund for the Development of Slums and the start of its development. She is currently working as Assistant Professor at Delta University for Science \& Technology, Faculty of Engineering, Department of Architectural, International Coastal Road, Gamasa city, Mansoura, Dakhliya, Egypt. She obtained her $\mathrm{PhD}$ (Architecture), Master of Architecture, Bachelor of Architecture from Mansoura University. She taught architectural design, urban planning, project management and execution drawings. Its current research interests on Slum's development and sustainable urban planning.

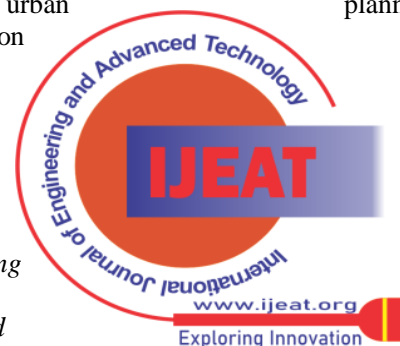

